\title{
Fiscal Decentralization and Economic Growth in the United States*
}

\author{
D anyang $X$ ie \\ Hong Kong University of Science and Technology, Hong Kong \\ Heng-fu Zou ${ }^{\dagger}$ \\ Institute for Advanced Studies, Wuhan University, China and Development Research \\ Group, World Bank, Washington, DC 20433
}

and

Hamid Davoodi

International Monetary Fund, Washington, DC 20431

Received M ay 16, 1997; revised February 13, 1998

In a simple model of endogenous growth with spending by different levels of government, we demonstrate how fiscal decentralization affects the long-run growth rate of the economy. A pplying the model to the U.S. economy, we find that the existing spending shares for state and local governments have been consistent with growth maximization. In this sense, further decentralization in public spending may be harmful for growth. (1999 A cademic Press

\section{INTRODUCTION}

Fiscal decentralization, the devolution of fiscal responsibilities of the federal government to state and local governments, is seen as a means to enhance the efficiency of the government and promote economic development and growth. This argument is clearly stated by 0 ates [13]:

The basic economic case for fiscal decentralization is the enhancement of economic efficiency: the provision of local outputs that are differentiated according

* We thank A maresh Bagchi, R ichard Bird, Shantayanan D evarajan, $\mathrm{N}$ an Li, Wallace $\mathrm{O}$ ates, $Y$ ingyi Q ian, Barry Weingast, Shlomo $Y$ itzhaki, Dingsheng Z hang, and especially two referees and J an Brueckner for comments, criticism, and suggestions. A ny errors remain ours.

${ }^{\dagger} M$ ailing address: The World Bank, Room M C2-611, 1818 H Street, N.W. Washington, DC 20433. 
to local tastes and circumstances results in higher levels of social welfare than centrally determined and more uniform levels of outputs across all jurisdictions. Although this proposition has been developed mainly in a static context (see my treatment of the Decentralization Theorem, 0 ates [11]), the thrust of the argument should also have some validity in a dynamic setting of economic growth. There surely are strong reasons, in principle, to believe that policies formulated for the provision of infrastructure and even human capital that are sensitive to regional or local conditions are likely to be more effective in encouraging economic development than centrally determined policies that ignore these geographical differences.

This argument has been supported by many experts on fiscal federalism and local government finance (Rivlin [15]; Bird [3]; Gramlich [8]; Sylla, Wallis, and Legler [16]). In practice, most developing countries have been decentralizing public spending and revenue collection from central governments to local governments (Dillinger [7]), whereas many developed economies such as the $U$ nited States, the $U$ nited $K$ ingdom, and Canada are reviving debates on fiscal decentralization or devolution. The case is especially pertinent for the U nited States. In recent years, the U.S. Congress has been contemplating eliminating hundreds of federal programs, replacing some with block grants to state and local governments, and ending the so-called unfunded federal mandates.

$\mathrm{H}$ owever, it is surprising that the few existing empirical studies have been unsuccessful in their efforts to substantiate the potential contribution of fiscal decentralization to economic growth and development. Davoodi and Zou [5], and Z hang and Zou [17] have taken a first step toward quantifying the growth effects of fiscal decentralization and aggregate public spending by different levels of government. So far they have only found a negative association between output growth and fiscal decentralization in their crosscountry study, as well as a country case study on China.

In this paper we set up a general analytical model linking fiscal decentralization to economic growth and then apply our analytical framework to the U.S. economy over the past four decades to test the significance of efficiency gains from fiscal decentralization.

\section{A GROWTH MODEL WITH DIFFERENT LEVELS OF GOVERNMENT SPENDING}

Following Barro [2], Devarajan, Swaroop, and Z ou [6], and Davoodi and Zou [5], the endogenous growth model consists of a production function with two inputs: private capital and public spending, where the function exhibits constant returns to scale in the two inputs. We depart from Barro's model by assuming that public spending is carried out by three levels of government: federal, state, and local. Let $k$ be private capital stock, $g$ the consolidated government spending, $f$ federal government spending, $s$ state 
government spending, and $l$ local government spending:

$$
f+s+l=g .
$$

The production function is CES:

$$
y=\left[\alpha k^{\phi}+\beta f^{\phi}+\gamma s^{\phi}+\omega l^{\phi}\right]^{1 / \phi}, \quad-\infty<\phi<1,
$$

where $\alpha, \beta, \gamma$, and $\omega$ are all in $(0,1)$ and $\alpha+\beta+\gamma+\omega=1$. The CES production function includes the Cobb-Douglas specification in $D$ avoodi and Zou [5] as a special case $(\phi=0)$. The introduction of public spending by different levels of government creates a potentially positive link between fiscal decentralization (i.e., differential effects of spending by three levels of government) and growth. As in Barro [2], when specifying the production function, we do not consider human capital and labor, but allow for these inputs in the empirical work.

The consolidated government spending $g$ is financed by a flat output tax at rate $\tau$ :

$$
g=\tau y \text {. }
$$

To derive the long-run growth rate of the economy, we first analyze the decisions made by the private sector. We consider a long-lived representative individual who maximizes his discounted utility,

$$
\max \int_{0}^{\infty}\left[\frac{c^{1-\sigma}-1}{1-\sigma}\right] e^{-\rho t} d t
$$

where $c$ is consumption of a single good produced in this economy; $\sigma$ is the inverse of the intertemporal elasticity of substitution; and $\rho$ is the rate of time preference. A $n$ overlapping-generations model addressing similar issues is presented by Brueckner [4].

The dynamic budget constraint he faces is:

$$
\dot{k}=(1-\tau)\left[\alpha k^{\phi}+\beta f^{\phi}+\gamma s^{\phi}+\omega l^{\phi}\right]^{1 / \phi}-c, \quad k_{0} \text { given. }
$$

The representative individual takes as given the government's announcement of the fixed tax rate $\tau$, and spending at different levels of governments, $f, s$, and $l$. He then chooses optimally the consumption path $\{c(t): t \geq 0\}$ and the path of the capital stock $\{k(t): t \geq 0\}$. To characterize the individual's optimal allocation of resources, we write down the Hamiltonian:

$$
H=\left[\frac{c^{1-\sigma}-1}{1-\sigma}\right]+\lambda\left\{(1-\tau)\left[\alpha k^{\phi}+\beta f^{\phi}+\gamma s^{\phi}+\omega l^{\phi}\right]^{1 / \phi}-c\right\} .
$$


The first-order conditions are given by

$$
\begin{gathered}
c^{-\sigma}=\lambda, \\
\dot{\lambda}=\rho \lambda-\lambda \alpha(1-\tau)\left[\alpha k^{\phi}+\beta f^{\phi}+\gamma s^{\phi}+\omega l^{\phi}\right]^{(1-\phi) / \phi} k^{\phi-1} .
\end{gathered}
$$

The transversality condition is $k \lambda e^{-\rho t} \rightarrow 0$ as $t$ approaches infinity.

Equations (5), (7), and (8) together with the initial condition and the transversality condition determine the representative individual's optimal responses. One immediate result from these equations is that the growth rate of consumption is given by

$$
\frac{\dot{c}}{c}=\frac{r(\mathrm{x})-\rho}{\sigma},
$$

where $\mathrm{x}$ denotes the vector $(k, f, s, l, \tau) ; r(\mathrm{x})$ has the interpretation of the real interest rate and is defined by

$$
r(\mathrm{x})=\alpha(1-\tau)\left[\alpha k^{\phi}+\beta f^{\phi}+\gamma s^{\phi}+\omega l^{\phi}\right]^{(1-\phi) / \phi} k^{\phi-1} .
$$

Let us define the spending shares for the federal, state, and local governments as $\varphi_{f}, \varphi_{s}$, and $\varphi_{l}$, respectively $\left(\varphi_{f}+\varphi_{s}+\varphi_{l}=1\right)$ :

$$
\varphi_{f}=\frac{f}{g}, \quad \varphi_{s}=\frac{s}{g}, \quad \varphi_{l}=\frac{l}{g} .
$$

Then, substituting (10) and (11) into (9), we obtain the long-run growth rate, $G$, of the economy explicitly as a function of various spending shares, income tax, and other exogenous factors:

$$
G=\frac{\alpha(1-\tau)}{\sigma}\left[\frac{\alpha \tau^{-\phi}}{\tau^{-\phi}-\beta \varphi_{f}^{\phi}-\gamma \varphi_{s}^{\phi}-\omega \varphi_{l}^{\phi}}\right]^{1-\phi / \phi}-\frac{\rho}{\sigma} .
$$

Thus the allocation of public spending among different levels of government can affect economic growth as seen from Eq. (12). To examine how the long-run growth rate responds to various spending shares and income tax rates, we assume that the government's objective is to maximize the growth rate in (12) by choosing $\tau, \varphi_{f}, \varphi_{s}$, and $\varphi_{l}$. This is the same as maximizing the individual's consumption growth (which coincides with the rate of growth of output and capital) in (9) subject to the government budget constraint of (3). Hence the problem can be formulated as one of maximizing (12) subject to

$$
f+s+l \leq \tau\left[\alpha k^{\phi}+\beta f^{\phi}+\gamma s^{\phi}+\omega l^{\phi}\right]^{1 / \phi} .
$$

The growth-maximizing tax rate is given in the following equation:

$$
\frac{\tau^{1-\phi}}{\phi \tau+(1-\phi)}=\Pi^{1-\phi}
$$

where $\Pi=\beta^{1 /(1-\phi)}+\gamma^{1 /(1-\phi)}+\omega^{1 /(1-\phi)}$. 
The growth-maximizing shares of federal, state, and local government spending are given by

$$
\begin{gathered}
\varphi_{f}^{*}=\frac{\beta^{1 /(1-\phi)}}{\Pi}, \\
\varphi_{s}^{*}=\frac{\gamma^{1 /(1-\phi)}}{\Pi}, \\
\varphi_{l}^{*}=\frac{\omega^{1 /(1-\phi)}}{\Pi} .
\end{gathered}
$$

Here we can interpret $\beta^{1 /(1-\phi)}, \gamma^{1 /(1-\phi)}$, and $\omega^{1 /(1-\phi)}$ as measures of individual productivity of public spending by the federal, state, and local governments, respectively. In the same light, $\Pi=\beta^{1 /(1-\phi)}+\gamma^{1 /(1-\phi)}+\omega^{1 /(1-\phi)}$ represents the aggregate productivity of all levels of government spending. From E qs. (15) to (17), it is apparent that the growth-maximizing spending shares are equal to the ratios of individual productivity over the aggregate productivity. If the actual spending shares do not correspond to these growth-maximizing shares, some reallocation of resources among the three levels of government will be growth-enhancing.

This point can be made most clearly in the case of the Cobb-Douglas production function. With the Cobb-D ouglas technology, $\phi=0$. Then, the growth-maximizing tax rate given by $\mathrm{Eq}$. (14) is very simple:

$$
\tau^{*}=\beta+\gamma+\omega
$$

which is the same as the formula in Barro [2] after making the notation consistent. $\Pi$ is simply equal to $(\beta+\gamma+\omega)$. The growth-maximizing shares of federal, state, and local government spending are also very simple as in Davoodi and Zou [5]:

$$
\begin{aligned}
\varphi_{f}^{*} & =\frac{\beta}{\beta+\gamma+\omega}, \\
\varphi_{s}^{*} & =\frac{\gamma}{\beta+\gamma+\omega}, \\
\varphi_{l}^{*} & =\frac{\omega}{\beta+\gamma+\omega} .
\end{aligned}
$$

It should be noted that we have focused on growth-maximizing spending shares and income taxation. Quite naturally, we may raise the issue that the government may maximize society's welfare. In general, growth maximization and welfare maximization lead to different tax rates and different spending shares for the three levels of government. However, if the production function is Cobb-Douglas, these two kinds of maximization yield the same solutions. ${ }^{1}$ 


\section{EMPIRICAL ANALYSIS}

To test the impact of fiscal decentralization on growth, we use annual historical time series for the U.S. economy from 1948 to 1994 . Following the public finance literature (e.g., 0 ates [12]) we measure fiscal decentralization as the share of spending by each level of government in consolidated government spending across all levels. A ceteris paribus rise in, say, the share of the federal government, indicates a lower degree of fiscal decentralization whereas a ceteris paribus rise in local government's share indicates a higher degree of fiscal decentralization.

Figure 1 plots these shares for three levels of government over the 194894 period. The share of state spending rose steadily from 15 to $30 \%$ over the 47 years, whereas local spending share fluctuated between 20 and 30\% during the same period. The federal spending share declined from $63 \%$ in the early 1950 s to $43 \%$ in 1994 . In calculating these spending shares, federal grants to lower levels of government are not counted as federal spending. At the same time, state spending includes the net grants received, which is defined as total grants received by state governments minus state transfers to local governments. Similarly, local spending includes all grants received.

In our theoretical analysis, the growth equation (12) expresses the growth rate of the economy as a function of the shares of government spending

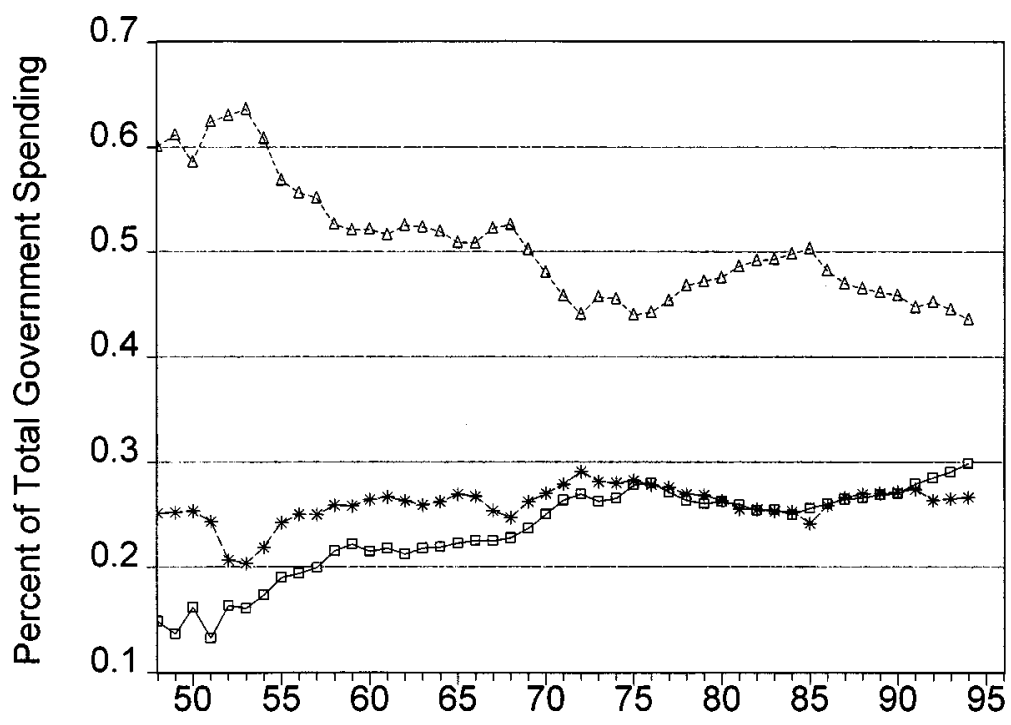

$\square$ State share $\ldots \ldots+\ldots$.... Federal share $\ldots-*--$ Local share

FIG. 1. Fiscal decentralization 1948-1994. 
at different levels and the tax rate. O ur estimated equation below can be thought of as a linear approximation of our nonlinear growth equation:

$$
\Delta y_{t}=x_{t}^{\prime} \delta+u_{t}
$$

where $\Delta$ is the difference operator, i.e., $\Delta y_{t}=y_{t}-y_{t-1}, y_{t}$ is the logarithm of per capita output; hence $\Delta y_{t}$ represents per capita output growth rate; $x_{t}$ consists of shares of government spending at different levels (measures of fiscal decentralization), the tax rate, and other determinants of growth; $\delta$ is the vector of parameters to be estimated; and $u_{t}$ is a disturbance term which may be serially correlated and/or correlated with some elements of $x_{t}$.

The detailed specification of variables in E q. (22) is as follows. Per capita output is measured by real per capita gross domestic product (GDP). We use our theoretical model as a guide to measure the tax rate and the shares of government spending at different levels. A ccordingly, the tax rate $\tau$ is defined as the ratio of the total consolidated receipts of government (i.e., net of intergovernmental grants) to GDP. It is therefore a measure of the average tax rate. In the previous section we already explained the construction of shares of government spending by different levels of government. These shares correspond to $\varphi_{f}, \varphi_{s}$, and $\varphi_{l}$ in our theoretical model. Please note that these shares may be a function of the rate of economic growth. But in this exploratory study we find it difficult to choose a good set of instruments to correct for this potential endogeneity of the spending shares. In reality, these spending shares are not only related to economic growth; they are also a product of political, institutional, and historical processes shaping the assignments of taxes and expenditures among the federal, state, and local governments. Hence, to offer a reasonable explanation for these spending shares amounts to studying how fiscal decentralization itself is determined, which shall be an important topic for further research.

In our empirical estimation, we also include a few other variables to test the robustness of our basic tax and spending share variables as the determinants of growth. These are the size of the labor force, the investment rate, a measure of external shock, two measures of the openness of the economy, the inflation rate, and a measure of income distribution (the Gini coefficient).

The Bureau of Labor Statistics' measure of the labor force, adjusted for different education levels of the working population, represents our candidate variable for labor quality or the stock of human capital. We refer to this variable as the labor quality index or labor. G ross private investment in fixed assets, as defined in the National Income and Product Accounts of the United States (NIPA), is used as a measure of private investment in physical capital.

A price index of energy products is used as a measure of external shocks. E nergy price shocks have always been cited as causes of growth slowdown 
in the U nited States and other industrialized countries; see, among others, $\mathrm{H}$ amilton [9]. We use the average tariff rate as one measure of the openness of the economy. It is defined as the ratio of total customs duties to total imports for consumption. A higher tariff rate indicates a less open economy. A Iternatively, we use the ratio of foreign trade volume over GDP as another measure of openness as in many empirical studies on economic growth; see Levine and Renelt [10]. In addition, we include the inflation rate and income distribution as two other control variables to test the robustness of our regression analysis; see L evine and R enelt [10]; A lesina and Rodrik [1]; and Persson and Tabellini [14].

We estimate the growth regression equation (22) using the technique of the ordinary least squares (OLS). The results are reported in Tables 1 and 2.

Table 1 shows our results for three levels of government. Since spending shares for three levels of government add up to unity, we only include two shares in the regression. For the three-level case, we include local and state spending shares, where the local level represents the lowest layer of the government. In Table 1 local spending share has a negative coefficient most of the time (six out of eight regressions), suggesting that higher fiscal decentralization may be associated with lower growth. But the $t$-statistics for the estimates are not very significant. In addition, the state spending share has a positive, but insignificant, coefficient for all eight regressions. On the basis of our theoretical, growth-maximizing model it is expected that a negative and significant coefficient on one of the government-share variables indicates that this level of government is relatively too large, whereas a positive and significant coefficient suggests that this level of government is relatively too small. Therefore, the insignificant coefficients on local and state spending shares may imply that the existing spending shares for local and state governments have been consistent with growth maximization. ${ }^{2}$ In this sense, further decentralization in public spending may be harmful for growth.

For other control variables in Table 1, the estimated coefficients are broadly consistent with other empirical studies on economic growth: higher growth is associated with lower energy prices, income inequality, tariff rate, inflation rate, tax rate and a higher investment rate, and more foreign trade.

Table 2 reports the OLS estimations of the growth regression for two levels of government for the same set of conditioning variables as in

\footnotetext{
${ }^{2}$ We should also acknowledge the alternate possibility that our model is incorrect and that the effects of public spending by different levels of government in the production function of E q. (2) are the same. That is to say, output depends only on aggregate government spending $g$ and not on the separate spending levels: $f, s$, and $l$. In this case, the spending shares are irrelevant to growth and should have no effect.
} 
TABLE 1

Dependent Variable: Per Capita O utput G rowth R ate (Three L evels of G overnment)

\begin{tabular}{|c|c|c|c|c|c|c|c|c|}
\hline $\begin{array}{l}\text { Estimation } \\
\text { technique } \\
\text { period }\end{array}$ & $\begin{array}{c}\text { OLS(1) } \\
1951- \\
1992\end{array}$ & $\begin{array}{c}\text { OLS(2) } \\
1951- \\
1991\end{array}$ & $\begin{array}{c}\text { OLS(3) } \\
1958- \\
1994\end{array}$ & $\begin{array}{c}\text { OLS(4) } \\
1958- \\
1991\end{array}$ & $\begin{array}{c}\text { OLS(5) } \\
1958- \\
1992\end{array}$ & $\begin{array}{c}\text { OLS(6) } \\
1958- \\
1991\end{array}$ & $\begin{array}{c}\text { OLS(7) } \\
1949- \\
1994\end{array}$ & $\begin{array}{c}\text { OLS(8) } \\
1949- \\
1991\end{array}$ \\
\hline Constant & $\begin{array}{c}0.05 \\
(0.12) \\
{[0.41]}\end{array}$ & $\begin{array}{c}0.01 \\
(0.11) \\
{[0.10]}\end{array}$ & $\begin{array}{c}0.30 \\
(0.14) \\
{[2.09]}\end{array}$ & $\begin{array}{c}0.24 \\
(0.15) \\
{[1.59]}\end{array}$ & $\begin{array}{c}0.33 \\
(0.14) \\
{[2.23]}\end{array}$ & $\begin{array}{c}0.27 \\
(0.15) \\
{[1.80]}\end{array}$ & $\begin{array}{c}0.07 \\
(0.11) \\
{[0.65]}\end{array}$ & $\begin{array}{c}0.05 \\
(0.10) \\
{[0.54]}\end{array}$ \\
\hline $\begin{array}{l}\text { A verage tax } \\
\text { rate }\end{array}$ & $\begin{array}{c}-0.15 \\
(0.40) \\
{[-0.37]}\end{array}$ & $\begin{array}{r}-0.03 \\
(0.39) \\
{[-0.07]}\end{array}$ & $\begin{array}{c}-0.67 \\
(0.41) \\
{[-1.64]}\end{array}$ & $\begin{array}{r}-0.53 \\
(0.45) \\
{[-1.17]}\end{array}$ & $\begin{array}{r}-0.72 \\
(0.43) \\
{[-1.65]}\end{array}$ & $\begin{array}{r}-0.60 \\
(0.45) \\
{[-1.32]}\end{array}$ & $\begin{array}{r}-0.22 \\
(0.38) \\
{[-0.58]}\end{array}$ & $\begin{array}{r}-0.18 \\
(0.37) \\
{[-0.49]}\end{array}$ \\
\hline $\begin{array}{l}\text { State government } \\
\text { spending share }\end{array}$ & $\begin{array}{c}0.04 \\
(0.41) \\
{[0.09]}\end{array}$ & $\begin{array}{c}0.07 \\
(0.41) \\
{[0.18]}\end{array}$ & $\begin{array}{c}0.44 \\
(0.42) \\
{[1.04]}\end{array}$ & $\begin{array}{c}0.37 \\
(0.52) \\
{[0.71]}\end{array}$ & $\begin{array}{c}0.54 \\
(0.49) \\
{[1.10]}\end{array}$ & $\begin{array}{c}0.47 \\
(0.52) \\
{[0.89]}\end{array}$ & $\begin{array}{c}0.15 \\
(0.34) \\
{[0.45]}\end{array}$ & $\begin{array}{c}0.25 \\
(0.36) \\
{[0.71]}\end{array}$ \\
\hline $\begin{array}{l}\text { Local government } \\
\text { spending share }\end{array}$ & $\begin{array}{c}0.06 \\
(0.43) \\
{[0.14]}\end{array}$ & $\begin{array}{c}0.04 \\
(0.42) \\
{[0.10]}\end{array}$ & $\begin{array}{c}-0.77 \\
(0.51) \\
{[-1.51]}\end{array}$ & $\begin{array}{c}-0.64 \\
(0.55) \\
{[-1.16]}\end{array}$ & $\begin{array}{c}-0.91 \\
(0.54) \\
{[-1.69]}\end{array}$ & $\begin{array}{c}-0.77 \\
(0.55) \\
{[-1.38]}\end{array}$ & $\begin{array}{r}-0.06 \\
(0.36) \\
{[-0.17]}\end{array}$ & $\begin{array}{c}-0.12 \\
(0.35) \\
{[-0.34]}\end{array}$ \\
\hline $\begin{array}{l}\text { Labor growth } \\
\text { rate }\end{array}$ & $\begin{array}{c}-0.07 \\
(0.58) \\
{[-0.12]}\end{array}$ & $\begin{array}{c}0.07 \\
(0.56) \\
{[0.13]}\end{array}$ & $\begin{array}{c}0.55 \\
(0.65) \\
{[0.84]}\end{array}$ & $\begin{array}{c}0.74 \\
(0.69) \\
{[1.07]}\end{array}$ & $\begin{array}{c}0.52 \\
(0.67) \\
{[0.77]}\end{array}$ & $\begin{array}{c}0.65 \\
(0.67) \\
{[0.96]}\end{array}$ & $\begin{array}{c}-0.06 \\
(0.53) \\
{[-0.11]}\end{array}$ & $\begin{array}{r}-0.06 \\
(0.53) \\
{[-0.12]}\end{array}$ \\
\hline $\begin{array}{l}D(\text { Log(Private } \\
\text { physical capital } \\
\text { investment }))\end{array}$ & $\begin{array}{c}0.12 \\
(0.03) \\
{[3.74]}\end{array}$ & $\begin{array}{c}0.11 \\
(0.03) \\
{[3.61]}\end{array}$ & $\begin{array}{c}0.11 \\
(0.03) \\
{[3.25]}\end{array}$ & $\begin{array}{c}0.10 \\
(0.03) \\
{[2.94]}\end{array}$ & $\begin{array}{c}0.09 \\
(0.03) \\
{[2.90]}\end{array}$ & $\begin{array}{c}0.09 \\
(0.03) \\
{[2.86]}\end{array}$ & $\begin{array}{c}0.13 \\
(0.02) \\
{[4.74]}\end{array}$ & $\begin{array}{c}0.12 \\
(0.02) \\
{[4.72]}\end{array}$ \\
\hline$D$ (O penness) & $\begin{array}{c}0.52 \\
(0.44) \\
{[1.16]}\end{array}$ & $\begin{array}{c}0.15 \\
(0.45) \\
{[0.32]}\end{array}$ & & & $\begin{array}{c}0.99 \\
(0.50) \\
{[1.95]}\end{array}$ & $\begin{array}{c}0.59 \\
(0.56) \\
{[1.05]}\end{array}$ & & \\
\hline $\begin{array}{l}D \text { (A verage tariff } \\
\text { rate) }\end{array}$ & & & $\begin{array}{c}-1.57 \\
(1.14) \\
{[-1.37]}\end{array}$ & $\begin{array}{c}-0.61 \\
(1.26) \\
{[-0.48]}\end{array}$ & & & $\begin{array}{r}-1.23 \\
(0.96) \\
{[-1.27]}\end{array}$ & $\begin{array}{r}-0.68 \\
(0.96) \\
{[-0.71]}\end{array}$ \\
\hline Inflation rate & $\begin{array}{r}-0.49 \\
(0.15) \\
{[-3.10]}\end{array}$ & $\begin{array}{r}-0.50 \\
(0.14) \\
{[-3.41]}\end{array}$ & & & & & $\begin{array}{r}-0.44 \\
(0.14) \\
{[-2.99]}\end{array}$ & $\begin{array}{r}-0.49 \\
(0.14) \\
{[-3.42]}\end{array}$ \\
\hline $\begin{array}{l}D(\log (\text { Price } \\
\text { of energy }))\end{array}$ & & & $\begin{array}{c}-0.12 \\
(0.05) \\
{[-2.13]}\end{array}$ & $\begin{array}{c}-0.11 \\
(0.05) \\
{[-2.07]}\end{array}$ & $\begin{array}{r}-0.14 \\
(0.05) \\
{[-2.45]}\end{array}$ & $\begin{array}{r}-0.13 \\
(0.05) \\
{[-2.30]}\end{array}$ & & \\
\hline$D$ (G ini) & & $\begin{array}{c}-0.01 \\
(0.01) \\
{[-2.43]}\end{array}$ & & $\begin{array}{c}-0.02 \\
(0.01) \\
{[-1.89]}\end{array}$ & & $\begin{array}{c}-0.01 \\
(0.01) \\
{[-1.62]}\end{array}$ & & $\begin{array}{c}-0.01 \\
(0.01) \\
{[-2.75]}\end{array}$ \\
\hline $\begin{array}{l}\text { A djusted } \\
\qquad R \text {-squared }\end{array}$ & 0.40 & 0.47 & 0.37 & 0.41 & 0.40 & 0.43 & 0.45 & 0.53 \\
\hline $\begin{array}{l}\text { Number of } \\
\text { observations }\end{array}$ & 42 & 41 & 37 & 34 & 35 & 34 & 46 & 43 \\
\hline
\end{tabular}

Notes: $D x_{t}=x_{t}-x_{t-1}$. Standard errors and $t$-statistics are given in parentheses and brackets respectively. $\mathrm{OLS}=$ ordinary least squares. 
FISCAL DECENTRALIZATION AND THE ECONOMY IN THE U.S.

TABLE 2

Dependent Variable: Per Capita O utput Growth R ate (Two L evels of Government)

\begin{tabular}{|c|c|c|c|c|c|c|c|c|}
\hline $\begin{array}{l}\text { Estimation } \\
\text { technique } \\
\text { period }\end{array}$ & $\begin{array}{l}\text { OLS(1) } \\
1951- \\
1992\end{array}$ & $\begin{array}{c}\text { OLS(2) } \\
1951- \\
1991\end{array}$ & $\begin{array}{c}\text { OLS(3) } \\
1958- \\
1994\end{array}$ & $\begin{array}{c}\text { OLS(4) } \\
1958- \\
1991\end{array}$ & $\begin{array}{l}\text { OLS(5) } \\
1958- \\
1992\end{array}$ & $\begin{array}{c}\text { OLS(6) } \\
1958- \\
1991\end{array}$ & $\begin{array}{l}\text { OLS(7) } \\
1949- \\
1994\end{array}$ & $\begin{array}{c}\text { OLS(8) } \\
1949- \\
1991\end{array}$ \\
\hline Constant & $\begin{array}{l}0.05 \\
(0.04) \\
{[1.32]}\end{array}$ & $\begin{array}{c}0.01 \\
(0.04) \\
{[0.18]}\end{array}$ & $\begin{array}{c}0.11 \\
(0.06) \\
{[1.72]}\end{array}$ & $\begin{array}{c}0.10 \\
(0.07) \\
{[1.36]}\end{array}$ & $\begin{array}{c}0.13 \\
(0.07) \\
{[1.77]}\end{array}$ & $\begin{array}{c}0.11 \\
(0.07) \\
{[1.44]}\end{array}$ & $\begin{array}{c}0.03 \\
(0.03) \\
{[1.15]}\end{array}$ & $\begin{array}{c}0.01 \\
(0.03) \\
{[0.04]}\end{array}$ \\
\hline $\begin{array}{l}\text { A verage tax } \\
\text { rate }\end{array}$ & $\begin{array}{r}-0.15 \\
(0.21) \\
{[-0.74]}\end{array}$ & $\begin{array}{c}-0.01 \\
(0.21) \\
{[-0.01]}\end{array}$ & $\begin{array}{r}-0.19 \\
(0.24) \\
{[-0.79]}\end{array}$ & $\begin{array}{c}-0.13 \\
(0.24) \\
{[-0.55]}\end{array}$ & $\begin{array}{c}-0.16 \\
(0.25) \\
{[-0.64]}\end{array}$ & $\begin{array}{l}-0.12 \\
(0.247) \\
{[-0.51]}\end{array}$ & $\begin{array}{c}-0.11 \\
(0.19) \\
{[-0.58]}\end{array}$ & $\begin{array}{c}-0.01 \\
(0.19) \\
{[-0.02]}\end{array}$ \\
\hline $\begin{array}{l}\text { State and local } \\
\text { government spending } \\
\text { share }\end{array}$ & $\begin{array}{l}0.05 \\
(0.12) \\
{[0.40]}\end{array}$ & $\begin{array}{c}0.06 \\
(0.11) \\
{[0.50]}\end{array}$ & $\begin{array}{r}-0.09 \\
(0.20) \\
{[-0.48]}\end{array}$ & $\begin{array}{r}-0.11 \\
(0.21) \\
{[-0.55]}\end{array}$ & $\begin{array}{r}-0.14 \\
(0.21) \\
{[-0.67]}\end{array}$ & $\begin{array}{r}-0.12 \\
(0.21) \\
{[-0.60]}\end{array}$ & $\begin{array}{c}0.04 \\
(0.12) \\
{[0.41]}\end{array}$ & $\begin{array}{c}0.06 \\
(0.11) \\
{[0.56]}\end{array}$ \\
\hline $\begin{array}{l}\text { Labor growth } \\
\text { rate }\end{array}$ & $\begin{array}{c}-0.07 \\
(0.56) \\
{[-0.13]}\end{array}$ & $\begin{array}{l}0.08 \\
(0.54) \\
{[0.14]}\end{array}$ & $\begin{array}{c}0.31 \\
(0.64) \\
{[0.48]}\end{array}$ & $\begin{array}{c}0.68 \\
(0.69) \\
{[0.98]}\end{array}$ & $\begin{array}{c}0.39 \\
(0.68) \\
{[0.58]}\end{array}$ & $\begin{array}{l}0.61 \\
(0.68) \\
{[0.89]}\end{array}$ & $\begin{array}{r}-0.05 \\
(0.52) \\
{[-0.11]}\end{array}$ & $\begin{array}{r}-0.03 \\
(0.52) \\
{[-0.06]}\end{array}$ \\
\hline $\begin{array}{l}D(\text { Log(Private } \\
\text { physical capital } \\
\text { investment }))\end{array}$ & $\begin{array}{c}0.11 \\
(0.03) \\
{[3.86]}\end{array}$ & $\begin{array}{c}0.11 \\
(0.02) \\
{[3.75]}\end{array}$ & $\begin{array}{l}0.12 \\
(0.03) \\
{[3.59]}\end{array}$ & $\begin{array}{c}0.11 \\
(0.03) \\
{[3.26]}\end{array}$ & $\begin{array}{c}0.10 \\
(0.03) \\
{[3.30]}\end{array}$ & $\begin{array}{c}0.10 \\
(0.03) \\
{[3.29]}\end{array}$ & $\begin{array}{c}0.13 \\
(0.02) \\
{[5.14]}\end{array}$ & $\begin{array}{c}0.13 \\
(0.02) \\
{[5.15]}\end{array}$ \\
\hline$D$ (O penness) & $\begin{array}{c}0.52 \\
(0.40) \\
{[1.29]}\end{array}$ & $\begin{array}{c}0.14 \\
(0.41) \\
{[0.34]}\end{array}$ & & & $\begin{array}{c}0.83 \\
(0.51) \\
{[1.63]}\end{array}$ & $\begin{array}{c}0.40 \\
(0.54) \\
{[0.73]}\end{array}$ & & \\
\hline $\begin{array}{l}D \text { (A verage } \\
\text { tariff rate) }\end{array}$ & (1.16) & (1.25) & $\begin{array}{c}-1.46 \\
{[-1.26]}\end{array}$ & $\begin{array}{c}-0.43 \\
{[-0.35]}\end{array}$ & $(0.91)$ & $(0.90)$ & $\begin{array}{l}-1.13 \\
{[-1.24]}\end{array}$ & $\begin{array}{c}-0.51 \\
{[-0.57]}\end{array}$ \\
\hline Inflation rate & $\begin{array}{c}-0.48 \\
(0.15) \\
{[-3.20]}\end{array}$ & $\begin{array}{r}-0.50 \\
(0.14) \\
{[-3.50]}\end{array}$ & & & & & $\begin{array}{c}-0.46 \\
(0.14) \\
{[-3.25]}\end{array}$ & $\begin{array}{c}-0.51 \\
(0.14) \\
{[-3.60]}\end{array}$ \\
\hline $\begin{array}{l}D(\log (\text { Price of } \\
\text { energy }))\end{array}$ & & & $\begin{array}{c}-0.13 \\
(0.05) \\
{[-2.33]}\end{array}$ & $\begin{array}{c}-0.12 \\
(0.05) \\
{[-2.12]}\end{array}$ & $\begin{array}{c}-0.14 \\
(0.06) \\
{[-2.43]}\end{array}$ & $\begin{array}{c}-0.13 \\
(0.06) \\
{[-2.24]}\end{array}$ & & \\
\hline$D$ (G ini) & & $\begin{array}{c}-0.01 \\
(0.01) \\
{[-2.47]}\end{array}$ & & $\begin{array}{c}-0.02 \\
(0.01) \\
{[-1.96]}\end{array}$ & & $\begin{array}{c}-0.01 \\
(0.01) \\
{[-1.78]}\end{array}$ & & $\begin{array}{c}-0.01 \\
(0.01) \\
{[-2.78]}\end{array}$ \\
\hline $\begin{array}{l}\text { A djusted } R \text {-squared } \\
\text { Number of observations }\end{array}$ & $\begin{array}{l}0.41 \\
42\end{array}$ & $\begin{array}{l}0.49 \\
41\end{array}$ & $\begin{array}{l}0.34 \\
37\end{array}$ & $\begin{array}{l}0.41 \\
34\end{array}$ & $\begin{array}{l}0.37 \\
35\end{array}$ & $\begin{array}{l}0.42 \\
34\end{array}$ & $\begin{array}{l}0.46 \\
46\end{array}$ & $\begin{array}{l}0.54 \\
43\end{array}$ \\
\hline
\end{tabular}

Notes: $D x_{t}=x_{t}-x_{t-1}$. Standard errors and $t$-statistics are given in parentheses and brackets, respectively. $\mathrm{OLS}=$ ordinary least squares.

Table 1. With two levels of government, federal and the combined state and local governments, only one spending share is included in the regression because of the adding-up property. We have included the spending share of the combined state and local governments as a measure of fiscal decentralization; a higher level of the combined share indicates a higher 
degree of fiscal decentralization. R esults in Table 2 show that the estimated coefficients for the combined state and local spending share have mixed signs and are highly insignificant, further indicating that the existing fiscal structure in public spending has been consistent with growth maximization. 0 ther variables in Table 2 have the same signs as in Table 1.

\section{CONCLUSION}

The main objective of this paper has been to provide theory and evidence on the relationship between fiscal decentralization and growth. In a simple model of endogenous growth with public spending by different levels of government, we have demonstrated how fiscal decentralization affects the long-run growth rate of the economy. Applying the model to the U.S. economy, we find that the existing spending shares for local and state governments are consistent with growth maximization. This finding holds for two as well as three levels of government. Our empirical examination is highly relevant for current policy debates on the allocation of federal grants and the assignment of expenditure responsibilities among the three levels of government in the $U$ nited States. If efficiency gains and growth are the main objectives for further fiscal decentralization in the U nited States, the empirical results of our study seem to suggest that this move may be harmful for growth.

\section{DATA APPENDIX}

The following data sources are used in this paper: Economic Report of the President (ERP), Historical Statistics of the U nited States, Colonial Times to 1970 (H SU S); H istorical A bstract of the U nited States (HAUS); National Income and Product Accounts of the U nited States, Volumes I and II, 1929-1988 (NIPA); Survey of Current Business (SCB); Facts and Figures on $G$ overnment $F$ inance (FFG F); B ureau of $L$ abor Statistics (BLS); Current Population Reports (CPR).

The variables as well as their sources used in this paper are civilian labor force (ERP; HSU S); population (ERP); imports and exports (ERP); gross domestic private investment (ERP); gross domestic product (ERP); consumer price index or inflation (ERP); total duties calculated and total imports for consumption (H SU S;H AU S); federal government expenditure, state and local government expenditure (NIPA ;SCB); state government direct expenditure, local government direct expenditure (HAU S;FFG F); federal grants-in-aid to state and local governments, federal government receipts, state and local government receipts (NIPA ;SCB); labor quality index or labor (BLS); price of energy (HSU S;HAU S;SCB); the Gini coefficient (CPR).

The data used in this study are available from the authors upon request. 


\section{REFERENCES}

1. A. A lesina and D. Rodrik, Distributive politics and economic growth, Quarterly Journal of Economics, 109, 465-490 (1994).

2. R. Barro, Government spending in a simple model of endogenous growth, Journal of Political Economy, 98, S103-S125 (1990).

3. R. Bird, Threading the fiscal labyrinth: Some issues in fiscal decentralization, National Tax Journal, XLVI, 207-227 (1993).

4. J. Brueckner, Fiscal federalism and capital accumulation, mimeo, Department of Economics, U niversity of Illinois at U rbana-Champaign (1996).

5. H. Davoodi and H. Zou, Fiscal decentralization and economic growth: A cross-country study, Journal of Urban Economics 43, 244-257 (1998).

6. S. D evarajan, V. Swaroop, and H. Zou, Composition of public spending and economic growth, Journal of Monetary Economics, 37, 313-344 (1996).

7. W. Dillinger, Decentralization and its implications for urban service delivery, working paper, The World Bank (1994).

8. E. Gramlich, A policy maker's guide to fiscal decentralization, National Tax Journal, XLVI, 229-235 (1993).

9. J. Hamilton, Oil prices and the macroeconomy since World War II, Journal of Political Economy, 91, 228-248 (1982).

10. R. L evine and D. R enelt, A sensitivity analysis of cross-country growth regressions, American Economic Review, 82, 942-963 (1992).

11. W. O ates, "Fiscal Federalism," H arcourt Brace J ovanovic, New York (1972).

12. W. O ates, Searching for Leviathan: An empirical study, American Economic Review, 75, 748-757 (1985).

13. W. O ates, Fiscal decentralization and economic development, National Tax Journal, XLVI, 237-243 (1993).

14. T. Persson and G. Tabellini, Is inequality harmful for growth? Theory and evidence, American Economic Review, 84, June: 600-621.

15. A. Rivlin, "Reviving the A merican Dream, The Economy, the States, and the Federal Government," Brookings Institution, Washington, D.C (1992).

16. R. Sylla, J. Wallis, and J. Legler, H istorical economics: US state and local government, NBER Reporter, Spring, 14-16 (1995).

17. T. Zhang and H. Zou, Fiscal decentralization, public spending, and economic growth in China" Journal of Public Economics, 67, 221-240 (1998). 